\title{
Determinants of island tourism development: The example of Dachangshan Island
}

\author{
Jun Yang ${ }^{\text {a, b, * }}$, Yuting Ge ${ }^{\mathrm{a}}$, Quansheng Ge ${ }^{\mathrm{b}}$, Jianchao Xi ${ }^{\mathrm{b}}$, Xueming $\mathrm{Li}^{\mathrm{a}}$ \\ a Liaoning Key Laboratory of Physical Geography and Geomatics, Liaoning Normal University, 116029, Dalian, China \\ ${ }^{\mathrm{b}}$ Institute of Geographic Sciences and Natural Resources Research, CAS, 100101, Beijing, China
}

\section{H I G H L I G H T S}

- Island tourism refers to the development of island improvement, complete facilities and functional upgrading.

- Taking Dachangshan Island as a representative case, we emphasize discussion on the overall island tourism effects.

- Paper, based on the continuous time and space expansion scales, reveals the characteristics of island tourism effects.

\section{A R T I C L E I N F O}

\section{Article history:}

Received 30 July 2015

Received in revised form 28 February 2016

Accepted 1 March 2016

Available online 9 March 2016

\section{Keywords:}

Island tourism

Tourism effects

Temporal and spatial evolution

Tourism land use

Mechanism analysis

\begin{abstract}
A B S T R A C T
Islands possess their own patterns of spatial and temporal evolution as tourist destinations. Taking Dachangshan Island as an example, two key stages were identified: a 'landscape-oriented' period from 2002 to 2009, and a 'background' stage from 2009 to 2012. Co-existing with both periods was changing spatial and land-use patterns of expansion and intensification. Using spatial mapping techniques, it was found that tourist resources were found to be the original driving force, tourist transportation and social and economic factors were endogenous determinants of change, and tourist enterprises and source markets subject to government policies the exogenous factors.
\end{abstract}

(c) 2016 Elsevier Ltd. All rights reserved.

\section{Introduction}

Island tourism is an important commercial pursuit that meets the needs of its participants by means of both natural and manufactured resources set in specific geographical spaces. Specifically, the term "island tourism" refers to the phenomenon of the development of tourism on an island that advances the establishment of family guesthouses, corporate hotels, and other related commercial areas, as well as an integration of the island's scenic spots and urban developments, which in turn can influence the island's local population growth, environmental improvement, completion of facilities, and functional upgrading.

With the current increase in the travel and recreational activities of the Chinese population, domestic island tourism offers

\footnotetext{
* Corresponding author.

E-mail addresses: yangjun@Innu.edu.cn (J. Yang), 1072378449@qq.com (Y. Ge) geqs@igsnrr.ac.cn (Q. Ge), xijc@igsnrr.ac.cn (J. Xi), lixueming999@163.com (X. Li).
}

significant potential for development. However, compared to existing literature on the mainland tourist industry and corresponding research into land use, prior studies regarding island tourism are at present scarce, and relatively little work has been carried out on the spatial and temporal variations of island land use categories. Therefore, the current paper proposes to present a comprehensive evaluation of the development of island tourism by analyzing the evolutionary characteristics and mechanisms of its effects, and, thereby, to provide accurate insights and contributions toward the sustainable future development of island tourism.

Historically, research into the effects of tourism began with inquiries into its economic effects. For example, Keynes (1936) advanced a multiplier principle using a macro-economic model that studied the relationship between the elements providing the foundation for explaining tourism effects and their related effects for researchers in this field of study. Recent international studies on the topic have typically focused on, for example, the evaluation of tourism land use (Balli, Balli \& et al, 2016; Lemelin R. H. et al., 2015; 
Ruhanen L. et al., 2015); tourism communities' participation (Lee, 2013; Yang et al., 2013); the sustainable development of tourism (Buckley, 2012; Budruk et al., 2011; Sanagustín Fons, 2011); and tourism and environmental protection (Wells, 2015; Zu-yong et al., 2013). Meanwhile, research studies in China concerning tourism have chiefly concentrated on tourist resorts (Liu, 2003; Wu, 1998); the evaluation of tourism's resources (Jiang et al., 2004; Li, 2000; Li et al., 2013); the development of tourist destinations (Ma, 2011; Ren \& Wang, 2011; Wang \& Zhu, 2012); tourism and urbanization (Chen \& Bao, 2012; Chen et al., 2008; Zhang et al., 2008), and so on. In much of the foregoing research, deliberations on the spatial and temporal evolution of the effects of island tourism have mainly centered on the development and research of island tourism's land use, and these international and domestic studies of tourism development have generated some useful preliminary findings.

Several studies have been conducted on tourist attractions, rural tourism, tourism urbanization, and other related subjects evaluated in terms of scales of tourism development. In China, Wu and Guo (1991) addressed variations in tourism-related land development by proposing constrained conditions of land use as well as a planning and management method. Shen and Tian (2010) and Zhu, Lu, and et al. (2012) demonstrated, from the perspective of cultural landscapes and geography, the significant effects of land use in relation to scenic spots. Concerning tourism and urbanization, or the gradual spread of correlated development, Xi, Zhao, and et al (2013) obtained some important results from their analysis of the spatial distribution and evolutionary characteristics of the use of land for tourism, as well as the spatial structural characteristics of "ReBAM" (recreational belt around metropolis) land use (Xi et al., 2013; Zhao, 2010). Additionally, in this era of mass participation in tourism, visiting the countryside has attracted new attention, and Loumou, Giourga, and et al (2000) have suggested that rural areas within island destinations could play important roles in the tourist industry while still remaining productive, recognizing the importance of developing rural tourism (Loumou et al., 2000; Zhu et al., 2012).

Of particular interest to the present study is the fact that, in recent years, a few Chinese researchers have studied the Changshan Islands (of which Dachangshan is one) with regard to the development of tourism, development evaluations, island land use, etc. In their study of Guanglu Island, Wang, Li, and et al. (2010) considered the development potential of tourist destinations by combining an evaluation of the island's resources with that of visitor psychology. Ke and Wang (2012) presented an evaluation model of sustainable development that incorporated the characteristics of the Changshan Islands alongside sustainable development theory. A few years earlier, Zhang and Wang (2007) discussed the comprehensive utilization of island land based on their analysis of island land-use characteristics.

In summary, the majority of prior tourism research comprises qualitative studies of the evaluation and development of tourism destinations and neglects to put forward or establish tourism landuse classifications incorporating different function types based on actual tourist activity. Moreover, most of the earlier studies are based on an evolutionary analysis of tourism land use, and lack a comprehensive consideration of overall island tourism effects. Taking Dachangshan Island as a representative case, this paper studies the comprehensive effects of island tourism over several years and presents the characteristics of island tourism effects over different time spans and through various tourism development stages, in order to provide novel insights into the Liaoning island's situation as well as an in-depth evaluation of island tourism development in this growing division of the travel and services sectors.

\section{Materials and methodology}

\subsection{Study area}

Dachangshan Island $\left(122^{\circ} 40^{\prime} 01^{\prime \prime} \mathrm{E}, 39^{\circ} 15^{\prime} 59^{\prime \prime} \mathrm{N}\right)$ is located off China's northeast coast, at the center of the Changshan archipelago to the southeast of the Liaodong Peninsula in Liaoning Province (Fig. 1). Situated across the sea from the Korean Peninsula, it has a land area of $31.79 \mathrm{~km}^{2}$ and a coastline of $94.4 \mathrm{~km}$. As well as being an island tourist region of northern China, Dachangshan was identified in China's Eleventh Five-Year Plan (2006-2010), in which Liaoning Province's coastal economic development was outlined, as part of a southern coastal recreational resort in the province.

Dachangshan Island is the seat of the government of Changhai County, which in turn is both the only island county in Northeast China and the only island border county of China. The county is under the administration of the port city of Dalian, and, in 2010, the Dalian municipal government and the municipal Party Committee made the decision that the Changshan Island chain would designate Dachangshan Island as a summer tourist resort as well as a provincial tourist resort. Consequently, tourism is now the mainstay industry of Dachangshan Island, and, as a study area, is typical and representative of other island tourism developments in China.

Since 2009, the Chinese government has invested in a construction scheme to connect Dachangshan Island with other islands along the coastal tourist region; specifically, 130 million yuan were invested in 2009 to improve the capacity of the island's substation, after which nearly 70 million yuan were invested to construct a large-scale integrated visitors' center, showcasing Dachangshan Island's unique cultural charm.

\subsection{Data sources}

Based on high-resolution, remote-sensing (SPOT 5; Spot Image, Toulouse, France) images and source for land use data from 2002, 2006, 2009, and 2012 (see Table 1), this paper classifies the land of Dachangshan Island into six types (see Table 2) by combining the statistical data and remote-sensing image characteristics of the study area in accordance with the current land use conditions of Dachangshan Island and the national standard for Current Land Use Classification (GB/T 21010-2007).

In this study, the area of land used for tourism was superimposed and matched to the graph of land use transferred through geographical information system technology (ArcGIS; Esri, Redlands, California, USA), investigated the type and distribution of tourism land use in different periods as well as against relative land-use policies, in order to acquire a distribution graph of the island's land use for the years 2002, 2006, 2009, and 2012.

\subsection{Methods}

\subsubsection{Technology roadmap}

A data preprocessing and "input" stage was necessary for the analysis of the spatial and temporal evolution characteristics of the island tourism effects. Furthermore, it was necessary for this stage to incorporate the research's remote-sensing images and land use, land classifications, and investigation data in order to acquire a unified geographical database with a consistent data structure. The subsystems comprised a tourism destination evolution model (Butler, R.W., 1980), which included the island tourism evolution stage; a measurement of changes in the island tourism landscape (AI), including the influence of island landscape changes on island tourism effects; and a measurement of changes 


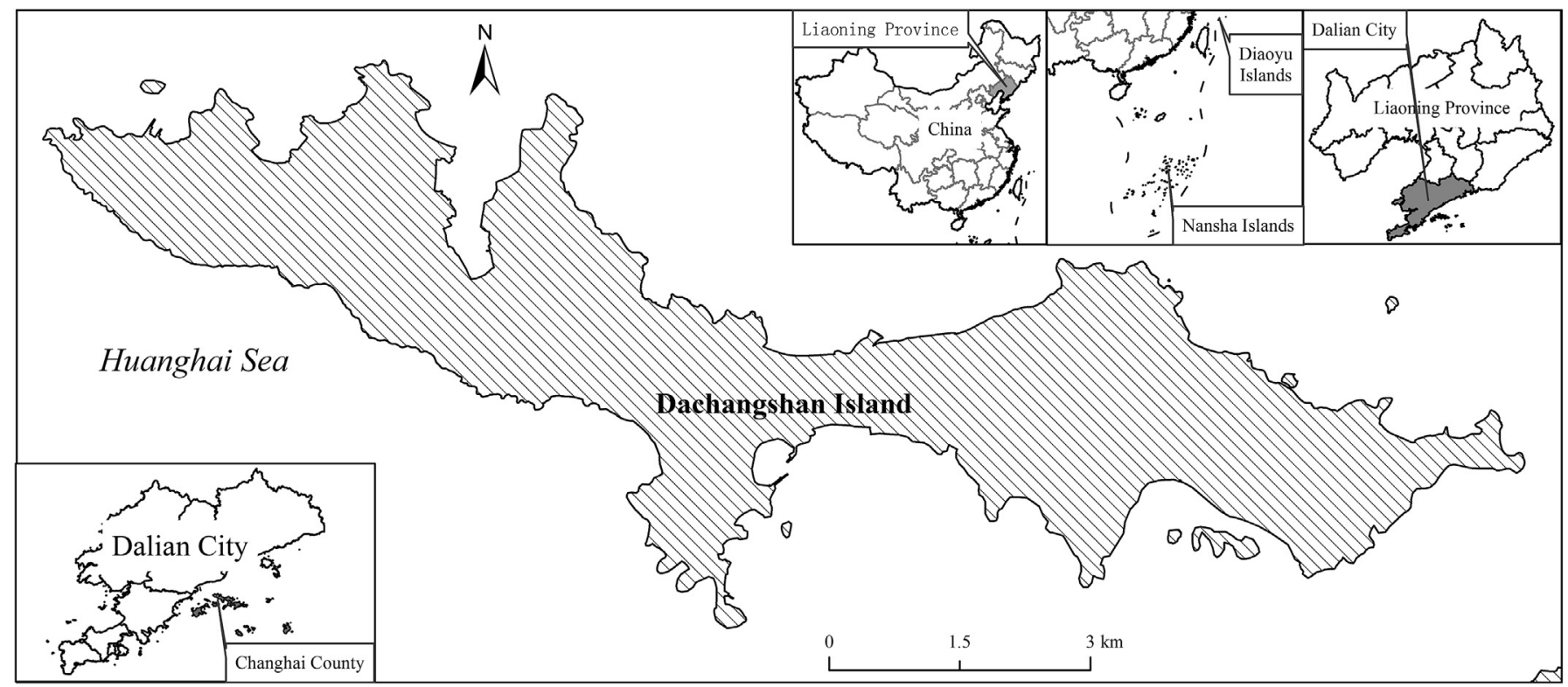

Fig. 1. The location of the study area, Dachangshan Island.

Table 1

Data sources and description.

\begin{tabular}{|c|c|c|c|}
\hline Date & Data type & Data attributes & Data source \\
\hline \multirow[t]{2}{*}{2002} & Land use data & scale $1: 10000$ & Remote sensing interpretation \\
\hline & $\begin{array}{l}\text { Remote-sensing } \\
\text { images }\end{array}$ & $\begin{array}{l}\text { SPOT } 5 \text { resolution: } \\
2.5 \mathrm{~m}\end{array}$ & $\begin{array}{l}\text { National Marine Environmental Monitoring Center (Dalian; State Oceanic Administration, Ministry of Land and } \\
\text { Resources, China) }\end{array}$ \\
\hline \multirow[t]{2}{*}{2006} & Land use data & scale $1: 10000$ & Remote sensing interpretation \\
\hline & $\begin{array}{l}\text { Remote-sensing } \\
\text { images }\end{array}$ & $\begin{array}{l}\text { SPOT } 5 \text { resolution: } \\
2.5 \mathrm{~m}\end{array}$ & $\begin{array}{l}\text { National Marine Environmental Monitoring Center (Dalian; State Oceanic Administration, Ministry of Land and } \\
\text { Resources, China) }\end{array}$ \\
\hline \multirow[t]{2}{*}{2009} & Land use data & scale $1: 10000$ & Remote sensing interpretation \\
\hline & $\begin{array}{l}\text { Remote-sensing } \\
\text { images }\end{array}$ & $\begin{array}{l}\text { SPOT } 5 \text { resolution: } \\
2.5 \mathrm{~m}\end{array}$ & $\begin{array}{l}\text { National Marine Environmental Monitoring Center (Dalian; State Oceanic Administration, Ministry of Land and } \\
\text { Resources, China) }\end{array}$ \\
\hline \multirow[t]{2}{*}{2012} & Land use data & scale $1: 10000$ & Remote sensing interpretation \\
\hline & $\begin{array}{l}\text { Remote-sensing } \\
\text { images }\end{array}$ & $\begin{array}{l}\text { SPOT } 5 \text { resolution: } \\
2.5 \mathrm{~m}\end{array}$ & $\begin{array}{l}\text { National Marine Environmental Monitoring Center (Dalian; State Oceanic Administration, Ministry of Land and } \\
\text { Resources, China) }\end{array}$ \\
\hline
\end{tabular}

Table 2

Land use classification system.

\begin{tabular}{|c|c|c|c|c|c|c|}
\hline \multicolumn{2}{|c|}{ First class } & \multicolumn{2}{|c|}{ Second class } & \multicolumn{2}{|c|}{ Third class } & \multirow[t]{2}{*}{ Explanation } \\
\hline Code & Name & Code & Name & Code & Name & \\
\hline \multirow[t]{2}{*}{1} & Land for agricultural & 11 & Cultivated land & - & - & Mainly plant crops \\
\hline & & 12 & Garden plots & - & - & Orchards, tea plantations, etc. \\
\hline \multirow[t]{2}{*}{2} & Land for construction & 21 & $\begin{array}{l}\text { Land used for rural and urban } \\
\text { residences }\end{array}$ & - & - & Urban and rural residential bases \\
\hline & & 22 & $\begin{array}{l}\text { Land used for the construction of } \\
\text { subsidiary support systems }\end{array}$ & - & - & $\begin{array}{l}\text { Land used in relation to residents' education, health } \\
\text { needs, etc. }\end{array}$ \\
\hline \multirow[t]{7}{*}{3} & Land for tourism & 31 & Land used for tourism-related retail & - & - & $\begin{array}{l}\text { Markets, shops selling travel-related items, pedestrian } \\
\text { streets with distinguishing features }\end{array}$ \\
\hline & & 32 & $\begin{array}{l}\text { Land used for tourism-related } \\
\text { catering }\end{array}$ & - & - & Restaurants, bars, food stalls in tourism destinations \\
\hline & & 33 & $\begin{array}{l}\text { Land used for tourism-related } \\
\text { entertainment }\end{array}$ & - & - & Natural landscapes as tourist attractions \\
\hline & & 34 & $\begin{array}{l}\text { Land used for tourism-related } \\
\text { lodgings }\end{array}$ & 341 & $\begin{array}{l}\text { Tourism land in rural } \\
\text { areas }\end{array}$ & Land for renovated farmhouses and subsidiary facilities \\
\hline & & & & 342 & Land used for hotels & Land for hotels and subsidiary facilities \\
\hline & & & & 343 & $\begin{array}{l}\text { Land used for high- } \\
\text { grade residences }\end{array}$ & Land for luxury hotels, resort hotels, villas \\
\hline & & 35 & Tourism-linked subsidiary land use & - & - & Subsidiary land except for tourism construction \\
\hline 4 & Land for transportation & - & - & - & - & Urban roads and land for transportation facilities \\
\hline 5 & $\begin{array}{l}\text { Water areas and land for water } \\
\text { conservancy facilities }\end{array}$ & - & - & - & - & $\begin{array}{l}\text { Land for continental water, tidal march channels, and } \\
\text { hydraulic structures }\end{array}$ \\
\hline 6 & Land for other use & - & - & - & - & Vacant land, bare land, and unused land \\
\hline
\end{tabular}

Note: Adopted from China's Current Land Use Classification (GB/T 21010-2007). 
in the island tourism function (IV) calculations, along with a measurement of changes among the island land functions. The research's results "output" stage showed the island tourism effects and their mechanism, based on the temporal and spatial characteristics of island land use, which combined the above parameters (see also Fig. 2).

\subsubsection{Tourism destination evolution model}

A conceptual model of tourism destination evolution charts the process by which a tourism destination evolves toward tourism under the influence of various factors. For example, with regard to island tourism, the entire evolution process can be divided into a "landscape tourism" stage and a "background tourism" stage. Landscape tourism is considered the first stage of tourism destination evolution, and, in the course of it, the tourism destination evolution model gives priority to landscape building and development, and the role of the government as the leading driving factors. Background tourism is the second stage of tourism destination evolution, and, in the course of this stage, the tourism destination evolution model gives priority to the management of the destination after the establishment, and the role of the government is relatively less important.

According to this conceptual model, tourism destination evolution can also be classified, according to the development stage and evolution characteristics, into "growth" types (" 1 " to " 5 "), "stable" types, and "degeneration" types ("6" to "9"). In the model used in this study (see Fig. 3), the subjects included government enterprise and tourists, while the driving forces came from benefits, environment, and policy initiatives, along with market factors, which were present throughout the entire evolution process (Yu \& Wang, 2007).

\subsubsection{Measurement of island tourism landscape changes}

Changes in an island tourism landscape are mainly reflected through changes in the island's tourism land use, which relates to the primitiveness of the island land and its building (Wang et al., 2010; Xi et al., 2013). In the present study, this evaluation was conducted with reference to construction, settlement, and tourism functions, using the following formula:

$A I=\sum_{i=1} p_{i} f_{i} / \sum_{i=1} p_{i} f_{\max }$

where $p$ stands for the evaluation index weight, the weighted value is acquired through an analytic hierarchical process $\sum p_{i}=1, f$ represents the value of the index value judgment, and $f_{\max }$ is the maximum value of the index.

\subsubsection{Measurement of island tourism function changes}

The land use scale adopts an expansion intensity index (M) to compare the intensity and speed of tourism land expansion during different periods of time (Liu \& Wu, 2000). The degree of functional change (IV) measure, indicating changes in the tourism land use function (Zhu et al., 2001), is calculated using Eq. (2):

$I V=\left(\frac{D_{i}}{D}+\frac{B_{i}}{B}\right) \times 100$

where $D_{i}$ represents the number of pattern spots of a certain change type, $D$ represents the number of pattern spots of all of the change types, $B_{i}$ is the total area of a certain change type, and $B$ is the total area of all of the change types.

\section{Results}

\subsection{Spatial and temporal pattern characteristics of the island's land use}

Temporal pattern characteristics of island land use can be expressed in terms of annual growth rate (AGR), as determined by

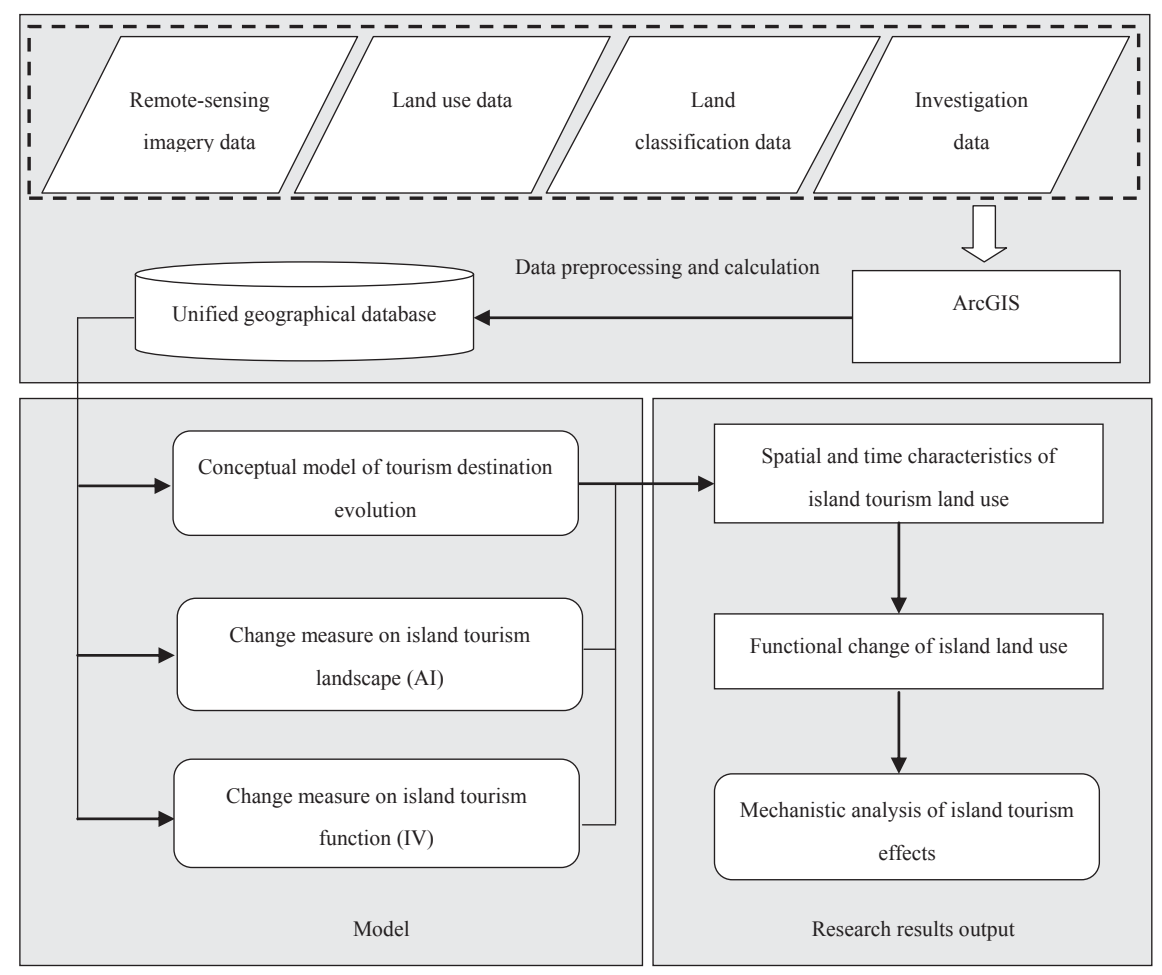

Fig. 2. Technology roadmap. 


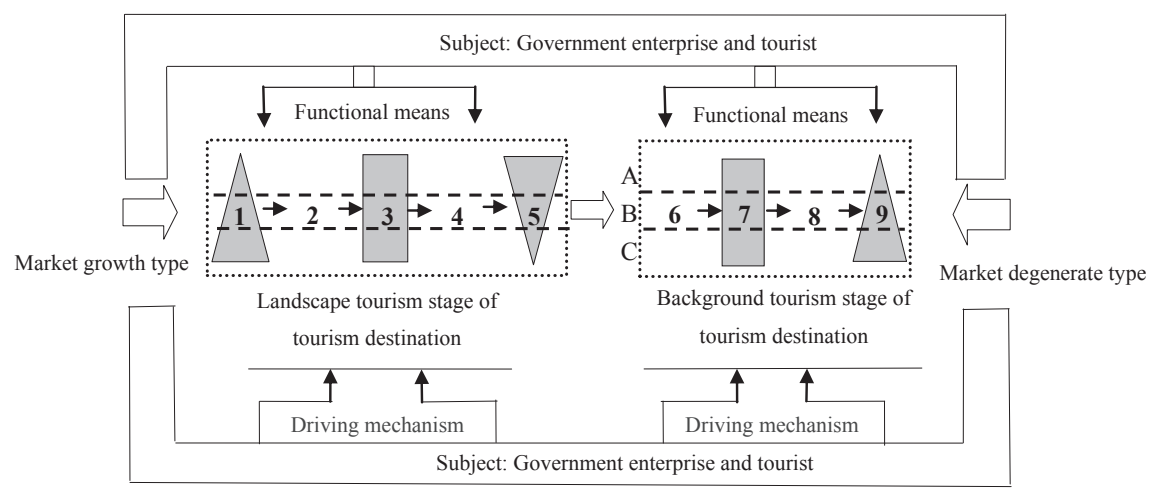

Fig. 3. Framework of the tourism destination evolution model. Note: $\mathrm{A}=$ tourism landscape ratio; $\mathrm{B}=$ transitional landscape ratio; $\mathrm{C}=$ non-tourism landscape ratio.

Eq. (3):

$A G R=\frac{A_{i+n}-A_{i}}{A_{i}} \times 100 \%$

where $A_{i}$ represents the total area of a certain type and $i$ denotes the years.

As detailed in Table 3, the total area of land used for tourism on Dachangshan Island increased by 56.84 square hectometers $\left(\mathrm{hm}^{2}\right)$ between 2002 and 2006, with an AGR of 8.66\%. The land used for tourist hotels showed the greatest increase, while that for executive residences showed the highest AGR value. From 2006 to 2009, the total land used for tourism increased by $196.13 \mathrm{hm}^{2}$, with an AGR of $27.52 \%$. The land used for tourist entertainment showed the greatest increase, while that for executive residences, as before, exhibited the highest AGR value. During this period, Dachangshan Island was in the growth type, landscape stage of a tourism destination (see Fig. 3). In the period 2009-2012, the total land used for tourism rose by $185.36 \mathrm{hm}^{2}$, with an AGR of $20.39 \%$. Within this time span, rural land used for tourism showed the greatest increase, while that for tourist hotels showed the largest AGR value. Also, during this period, the rate of increase of tourism on the island was slow and even, compared with the previous period, and was therefore concluded to be that of the stable, background tourism stage of a tourism destination.

The land used for tourism on Dachangshan Island was mainly sited in the rural areas, with less land used for tourist hotels and executive residences during the 2002-2006 period. However, between 2006 and 2009, the nature of tourism land use changed dramatically, with less used for tourist entertainment and tourist hotels and more for executive residences. Between 2009 and 2012, executive residential land use on Dachangshan Island expanded from the inland areas to the coastal regions. Generally speaking, the land used for tourism increased rapidly, the rural land used for tourism rose dramatically along the coastline, and the land used for tourist hotels and executive residences also formed subareas during the study period overall (2002-2012) (see Fig. 4).

With regard to changes in the island landscape recorded during the study period, there were fewer tourist buildings and more historical independent courtyards and renovated buildings, and the capacity to receive numbers of tourists was lower, with the authenticity of the island landscape found to be higher before 2002 . The construction of buildings for tourist accommodation became focused on the coastline, and both the diversity and convenience of public spaces on the island were improved during the period 2006-2009. However, during this time, the integrity of the settlement pattern declined and the authenticity of the island landscape was generally relatively low. From 2009 to 2012, the construction of high-rise buildings (with more than three floors) along the coastline and traffic routes rose significantly. Also, the function of the tourist infrastructure on the islands was found to have largely improved (see Tables 4 and 5).

\subsection{Changes in the island's land use functions}

As can be seen in the following depictions and descriptions of the overall type changes (e.g., Table 6) and status records of land use (Fig. 5) on Dachangshan Island between 2002 and 2012, the functions of the island's land gradually shifted from a single function to comprehensive and diversified functions. As indicated in the functional space patterns (see Fig. 4), the land for both urban and rural residences in the period 2002-2006 was focused at the center of the island, the land for tourism in the rural areas, and hotels were concentrated in the areas where the traffic routes and coastline intersected. The land used for urban and rural residences increasingly shifted to central settlements and was always adjacent to traffic routes. Also, the land used for tourism, especially tourism land in the rural areas, along with the land used for tourist hotels changed from a decentralized pattern to a centralized one during the period 2006-2009. The land used for both urban and rural residences gradually shrank (showing an increasing trend toward

Table 3

The scale of growth of land for tourism, 2002-2012.

\begin{tabular}{|c|c|c|c|c|c|c|c|}
\hline \multicolumn{2}{|l|}{ Type } & \multicolumn{2}{|l|}{$2002-2006$} & \multicolumn{2}{|l|}{ 2006-2009 } & \multicolumn{2}{|l|}{ 2009-2012 } \\
\hline & & Increment $\left(\mathrm{hm}^{2}\right)$ & AGR (\%) & Increment $\left(\mathrm{hm}^{2}\right)$ & AGR (\%) & Increment $\left(\mathrm{hm}^{2}\right)$ & AGR (\%) \\
\hline \multicolumn{2}{|c|}{ Land for tourism entertainment } & 12.97 & 2.2 & 64.46 & 10.74 & 35.17 & 5.29 \\
\hline \multirow[t]{3}{*}{ Land for tourism lodgings } & Tourism land in rural areas & 6.84 & 22.37 & 58.5 & 156.38 & 66.78 & 69.63 \\
\hline & Land for hotels & 24.22 & 903.7 & 20.44 & 75.99 & 54.08 & 114.24 \\
\hline & Land for high-grade residences & 9.59 & 198.55 & 49.57 & 343.76 & 28.1 & 43.91 \\
\hline \multicolumn{2}{|l|}{ Land for tourism subsidiaries } & 3.12 & 10.1 & 2.85 & 8.37 & 1.23 & 3.33 \\
\hline \multicolumn{2}{|l|}{ Total } & 56.84 & 8.66 & 196.13 & 27.52 & 185.36 & 20.39 \\
\hline
\end{tabular}

Notes: AGR = annual growth rate; $\mathrm{hm}^{2}=$ square hectometers. 

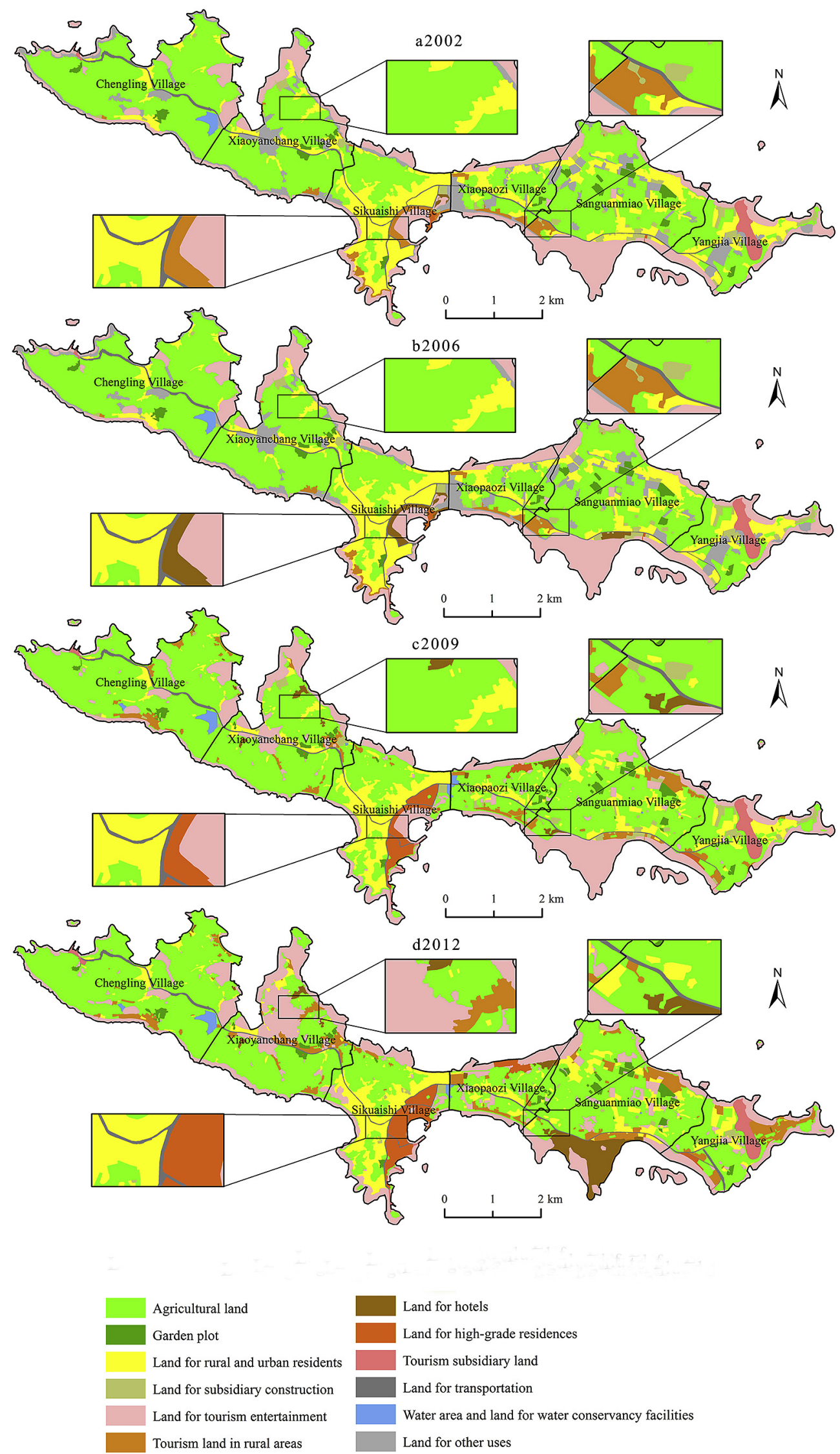

Fig. 4. Land use map of Dachangshan Island, 2002-2012 
Table 4

Authenticity evaluation results.

\begin{tabular}{lll}
\hline Key horizon & Index & Degree of landscape change (AI) \\
\hline Architecture & Long history of architecture & 0.243 \\
& Typicality of architecture style & 0.251 \\
Settlement & Local features of architecture model & 0.247 \\
& Variety of rural space & 0.325 \\
Tourism feature & Convenience of transportation in villages & 0.462 \\
& Integrity of settlement & 0.277 \\
& Features of natural resources & 0.239 \\
& Functionality of tourism infrastructure & 0.348 \\
& Tourism function of social and economic environments & 0.493 \\
\hline
\end{tabular}

Table 5

Authenticity evaluation index system.

\begin{tabular}{|c|c|c|c|c|c|c|}
\hline \multirow[t]{2}{*}{ Key horizon } & \multirow{2}{*}{\multicolumn{2}{|c|}{ Weight Index level }} & \multicolumn{4}{|c|}{ Weight Standard level } \\
\hline & & & & High ( $3-5$ points) & Medium (1-3 points) & Low (0-1 point) \\
\hline \multirow[t]{3}{*}{ Architecture } & 0.2635 & $\begin{array}{l}\text { Long history of } \\
\text { architecture }\end{array}$ & 0.1782 & $\begin{array}{l}\text { Architecture before Chinese economic } \\
\text { reform }\end{array}$ & $\begin{array}{l}\text { Architecture following Chinese } \\
\text { economic reform (1970s-1980s) }\end{array}$ & Architecture in the later 1990s \\
\hline & & $\begin{array}{l}\text { Typicality of } \\
\text { architecture style }\end{array}$ & 0.3246 & $\begin{array}{l}\text { Architecture with distinctive features of } \\
\text { period and region }\end{array}$ & $\begin{array}{l}\text { Architecture with more distinctive } \\
\text { features of period and region }\end{array}$ & $\begin{array}{l}\text { Architecture with no distinctive } \\
\text { features of period and region }\end{array}$ \\
\hline & & $\begin{array}{l}\text { Local features of } \\
\text { architecture model }\end{array}$ & 0.4972 & Traditional rural architecture & Blended architecture & Modern architecture \\
\hline \multirow[t]{3}{*}{ Settlement } & 0.3721 & $\begin{array}{l}\text { Variety of rural } \\
\text { space }\end{array}$ & 0.2153 & $\begin{array}{l}\text { Traditional public space (schools, village } \\
\text { committees, etc.) located in the center of } \\
\text { the village }\end{array}$ & $\begin{array}{l}\text { Public space } \\
\text { Not located in the center of the } \\
\text { village }\end{array}$ & Replaced by other public spaces \\
\hline & & $\begin{array}{l}\text { Convenience of the } \\
\text { transportation in } \\
\text { the village }\end{array}$ & 0.2698 & $\begin{array}{l}\text { Naturally formed, pavements made of } \\
\text { natural material, low degree of } \\
\text { connectivity }\end{array}$ & Relatively accessible, smooth & $\begin{array}{l}\text { Forming a network with well- } \\
\text { developed transportation }\end{array}$ \\
\hline & & $\begin{array}{l}\text { Integrity of } \\
\text { settlement }\end{array}$ & 0.5149 & $\begin{array}{l}\text { Completely preserved natural formation } \\
\text { and natural settlement with a total area of } \\
\text { more than } 75 \% \text { of the original area }\end{array}$ & $\begin{array}{l}\text { Partly altered settlement, with a } \\
\text { preserved area of more than } 25 \% \text { or } \\
\text { less than } 75 \% \text { of the original area }\end{array}$ & $\begin{array}{l}\text { Historical formation is replaced by } \\
\text { modern settlement, with a preserved } \\
\text { area of less than } 25 \% \text { of the original area }\end{array}$ \\
\hline \multirow[t]{3}{*}{$\begin{array}{l}\text { Tourism } \\
\text { features }\end{array}$} & 0.3644 & $\begin{array}{l}\text { Features of natural } \\
\text { resources }\end{array}$ & 0.1944 & $\begin{array}{l}\text { Beautiful natural environment with } \\
\text { distinctive tourism features }\end{array}$ & $\begin{array}{l}\text { More beautiful natural environment } \\
\text { with more distinctive tourism } \\
\text { features }\end{array}$ & $\begin{array}{l}\text { Common natural environment with no } \\
\text { distinctive tourism features }\end{array}$ \\
\hline & & $\begin{array}{l}\text { Functionality of } \\
\text { tourism } \\
\text { infrastructure }\end{array}$ & 0.3795 & $\begin{array}{l}\text { Low tourism reception capacity with no } \\
\text { attractive entertainment program }\end{array}$ & $\begin{array}{l}\text { Relatively high tourism reception } \\
\text { capacity with a few entertainment } \\
\text { programs }\end{array}$ & $\begin{array}{l}\text { High tourism reception capacity with } \\
\text { different kinds of attractive } \\
\text { entertainment programs }\end{array}$ \\
\hline & & $\begin{array}{l}\text { Tourism function } \\
\text { of social and } \\
\text { economic } \\
\text { environment }\end{array}$ & 0.4261 & Low combination degree of tourism land & $\begin{array}{l}\text { Relatively high combination degree } \\
\text { of tourism land }\end{array}$ & $\begin{array}{l}\text { High combination degree of tourism } \\
\text { land }\end{array}$ \\
\hline
\end{tabular}

vertical space) and land used for tourism rose quickly during the period 2009-2012.

The changes in land use function (Fig. 5) indicate that land used for agriculture was the foundation of the other types of land transformation, and the land used for tourist entertainment was the dominant one of the various types of tourism destination. As shown in Fig. 6, the transformation of the land used for agriculture was the most complex; this land was converted to tourism land in rural areas, to land for tourist hotels, and to land for executive residences, respectively (see also Table 7 ). In addition, the land function change from agricultural to tourism pursuits in the rural areas was the most significant, with respect to land-use change types. Changes in garden plots, urban and rural residential land, land for subsidiary construction, and land used for tourist-related entertainment purposes were relatively modest, and these types of land were mainly converted to tourism-used land in the rural areas as well as to land used for tourist-related entertainment, etc.

\subsection{Mechanistic analysis of the island's tourism effects}

The "mechanism" of island tourism effects refers to the way in

Table 6

Changes in land use types during the study period.

\begin{tabular}{|c|c|c|}
\hline Original land type & New land type & Degree of functional change (IV) \\
\hline \multirow[t]{3}{*}{ Land for agriculture } & Tourism land in rural areas & 4.35 \\
\hline & Land for hotels & 1.46 \\
\hline & Land for high-grade residences & 1.69 \\
\hline \multirow[t]{2}{*}{ Garden plots } & Land for tourism-related entertainment & 1.15 \\
\hline & Agricultural land & 1.27 \\
\hline \multirow[t]{2}{*}{ Land for rural and urban residences } & Tourism land in rural areas & 2.59 \\
\hline & Land for tourism-related entertainment & 0.54 \\
\hline \multirow{2}{*}{ Land for subsidiary construction } & Tourism land in rural areas & 1.31 \\
\hline & Agricultural land & 0.20 \\
\hline \multirow[t]{2}{*}{ Land for tourism-related entertainment } & Tourism land in rural areas & 5.60 \\
\hline & Land for high-grade residences & 18.22 \\
\hline
\end{tabular}



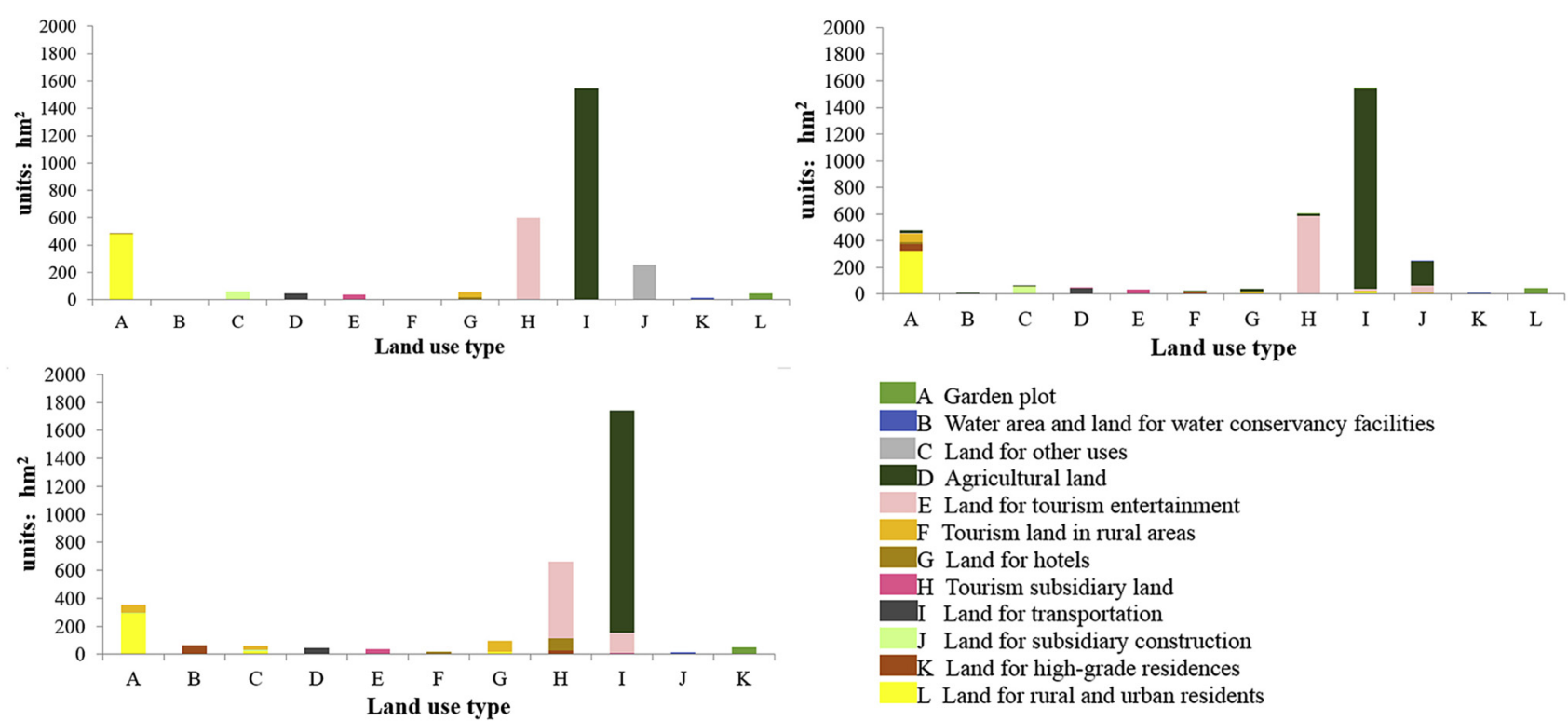

Fig. 5. Land use functional changes.

which an island is affected by tourism and how it changes as a result. The temporal and spatial evolution of island tourism's land use is an important manifestation of island tourism effects. Both tourist resources and tourist traffic, as well as social and economic factors, form the foundation of the endogenous driving force of island tourism effects, while government policies, tourist enterprises, and tourist source markets support the external drive of these effects.

\subsubsection{Endogenous driving factors of the island's tourism effects}

These comprise four main aspects, as follows:

(1) Tourist resources, especially tourist attractions, are the original driving force of island tourism effects. The development of tourism on Dachangshan Island was dependent on the unique advantages of the area it occupies. Various types of tourism land use were developed on the island, and these types of land use promoted the improvement of island tourism resources through cooperation and competition.

(2) Tourist traffic affected both the degree of distribution of regional tourism land and the close connection of the regional tourism system. During the development stage of the island's tourism effects, the road network was very good. However, the level of ring roads on the island, and their connectivity, were still not sufficient.

(3) Social factors were mainly reflected in the levels of coordination and cooperation among the local residents, which to a certain extent influenced the distribution of island tourism's land use as well as the evolution of island tourist effects. As part of a new round of the implementation of the strategy of rejuvenating northeast China, Dachangshan Island was rebranded as representing a "fisherman's family in Changhai," establishing fish and the related tourism as an important part of the future attraction and

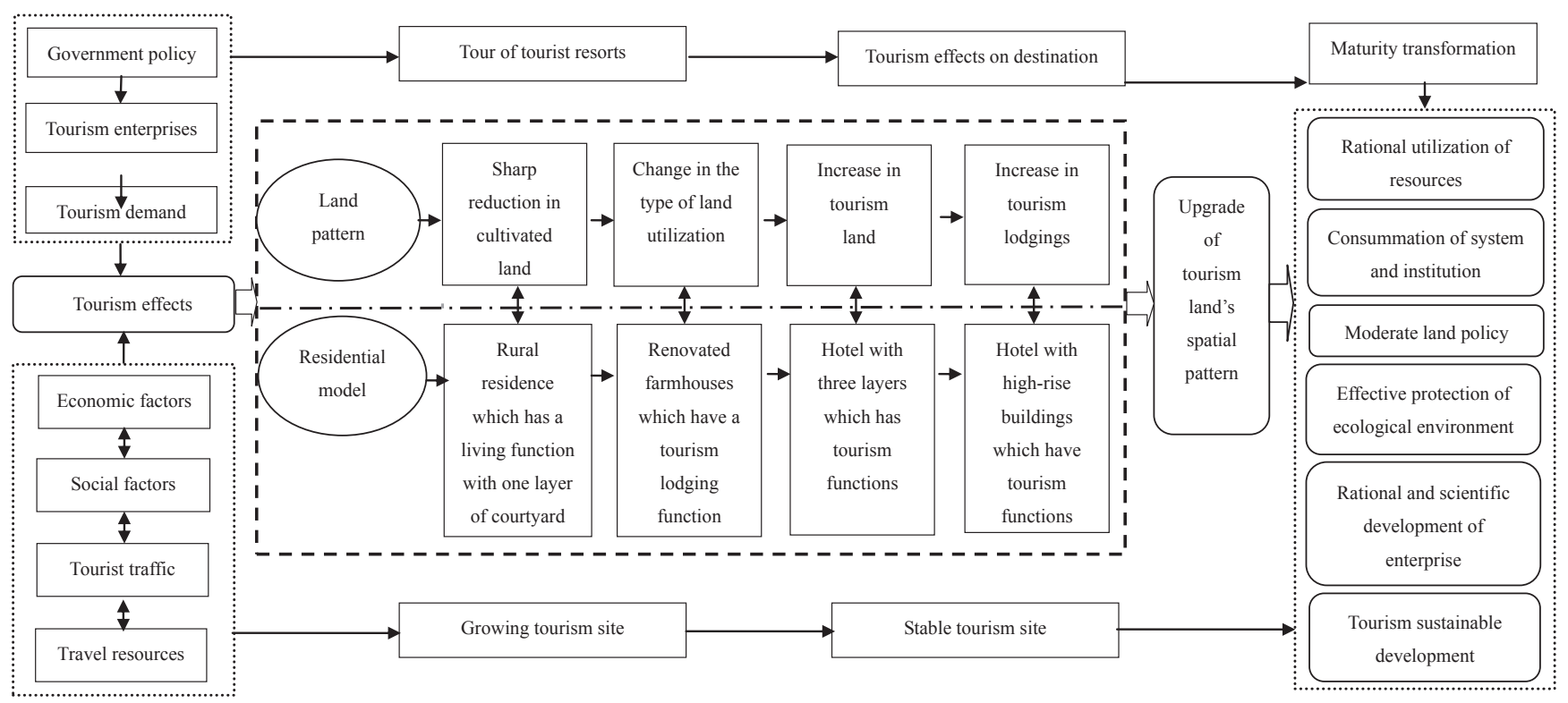

Fig. 6. Mechanistic analysis of tourism effects on Dachangshan Island. 
Table 7

Comparisons of accommodation type.

\begin{tabular}{|c|c|c|}
\hline $\begin{array}{l}\text { Tourism } \\
\text { fixation stage }\end{array}$ & Tourist accommodation mode & Sample representation \\
\hline $2002-2006$ & $\begin{array}{l}\text { Farm stays, which were renovated from rural courtyards, included courtyard, semi-enclosed courtyard, and living and } \\
\text { tourism functions. }\end{array}$ & 海. 旺 \\
\hline 2006-2009 & $\begin{array}{l}\text { The transition from farm stay to tourist hotels, which included three-story buildings with no courtyard, weakened the } \\
\text { residential function. Meanwhile, the tourist accommodation function accounted for the main part, and the courtyard's rural } \\
\text { functions were gradually lost. }\end{array}$ & \\
\hline 2009-2012 & $\begin{array}{l}\text { During the transition from tourist hotel to high-grade residential land, high-ranking hotels and high-rise buildings with no } \\
\text { open courtyards and no open living space sprang up. The living function was lost, while the accommodation and reception } \\
\text { functions were continuously enriched and improved. }\end{array}$ & \\
\hline
\end{tabular}

success of the island. During the period of increasing island tourism effects, the residents of Dachangshan Island accomplished the transformation from farmer to tourism server and turned urban and rural residential areas into tourism land, with a consequently significant bearing on tourism effects.

(4) The importance of tourism effects is first reflected in economic factors. The economic benefits of tourism on Dachangshan Island both attracted tourism operators from other areas and stimulated the enthusiasm of resident farmers to participate in tourism development, especially during the coastal economic development period of China's Eleventh Five-Year Plan (2006-2010). The number of tourists and the comprehensive income index increased correspondingly, accelerating the effect of changes in the island tourism's land function and the area of distribution, and providing economic conditions for the landscape tourism stage of a tourism destination to the background tourism stage. Moreover, the accumulation of wealth through tourism business activities provides a basis for the improvement of tourism facilities by island tourism operators, thereby changing the use function of island tourism land and its distribution.

\subsubsection{External driving factors of the island's tourism effects}

In the process of increasing tourism effects on Dachangshan Island, external factors on the promotion of in-depth island tourism included policies, tourism planning, and tourism demands. These factors played different roles in the two stages of the island's tourism growth.

First, during the island's landscape tourism stage of becoming a tourism destination (2002-2009), the development of Dachangshan's tourism witnessed the growth type stage. During this period, the government played critical roles in the development of tourism by formulating a series of regulations and policies, such as the "Changhai incentives for the economic development of island tourism," which laid foundations for the evolution of the island's tourism land use and an improvement in tourism effects. By participating in tourism, many enterprises also played an active part in planning and developing island tourism during this period. At the same time, organized tourism projects attracted reasonable investment, and the Government offered tax relief to support enterprises involved in such projects' implementation. The increase in a tourist source market was a direct driving force in the landscape stage of the island's tourism destination development.
Second, during the background tourism stage of tourism destination development (2009-2012), Dachangshan Island's tourism experienced the stable stage of development. During this time, the governmental control and guidance of the island's tourism destination development represented a "Government regulation, market dominant distribution" model in which land use policies associated with tourism development were formed and remained stable. With regard to the participation of enterprises, most of the small tourism-related businesses reconstructed their reception facilities in order to improve their functionality and increased the island's tourism's development by working together; most of the small tourism enterprises continuously improved their facilities, and completed and signed a "No malicious demand guarantee of competition" concerning fishermen's hotel enterprises. Thus, enterprises worked together with the island's residents for the purpose of building a service-oriented tourism destination.

\section{Conclusions and discussion}

Taking Dachangshan Island as an example, this paper has analyzed the spatial and temporal evolution characteristics of island tourism effects on the Changshan Islands through consideration of the relative importance of a tourism destination's evolution model, its tourism destination authenticity indices, and its tourism function changes. The results of this analysis suggested the following conclusions in respect of the island:

(1) Within the space and time expansion scales of tourism land use, time expansion and spatial expansion coexisted. The maximal growth rate changed from early executive-residential land use to tourist-hotel land use. Overall, the land used for tourism increased rapidly, rural land used for tourism rose sharply along the coastline, and the land used for tourist hotels, along with executive residences, also increased and gradually formed subareas.

(2) In terms of the expansion intensity of tourism land use, the spatial expansion changed from a horizontal to a vertical expansion during the island's evolutionary process from landscape tourism to a background tourism destination. By focusing on the reconstruction of tourist reception facilities, the degree of intensity of land use rose substantially.

(3) With respect to functional changes of tourism land use, the island land function gradually transformed from a single function to several comprehensive and diversified functions. Among these, 
the land used for agriculture formed the main foundation for the other types of land use transformation, while that used for tourismrelated entertainment represented the dominant direction of the various types of tourism land use.

(4) Mechanistically, these changes in island tourism suggested that tourist resources were the original driving force, while tourist transportation, along with social and economic factors, were the endogenous driving forces. In addition, tourist enterprises and tourist source markets were found to be the external driving forces, under the guidance of government policy.

Finally, it was noted that, during the process of tourism development, some problems still existed, such as environmental pollution ; (Katircioglu and Salih T, 2014; Zhang \& Gao, 2007), incomplete tourist planning, the need to progress relevant systems and policies (Dredge \& Jamal, 2015; Estol \& Font, 2016), and so on. Therefore, during the process of island tourism development, reasonable use of resources must be stressed, systems must be improved, effective measures for the protection of the ecological environment must be put into place, and the systematic development of enterprises must be utilized in order to achieve sustainable development.

\section{Acknowledgments}

This research study was supported by the National Natural Science Foundation of China (Grant No. 41471140) and Liaoning Province Outstanding Youth Program (Grant No. LJQ2015058). The authors would like to acknowledge all experts contributions in the building of the model and the formulation of the strategies of this study. We sincerely thank the Dalian Municipal Bureau of Land Resources and Housing for providing the data for this study.

\section{References}

Balli, F., Balli, H. O., \& Jean, L. (2016). The impacts of immigrants and institutions on bilateral tourism flows. Tourism Management, 52, 221-229.

Buckley, R. (2012). Sustainable tourism: research and reality. Annals of Tourism Research, 39, 528-546.

Budruk, M., Phillips, R., Cole, S., \& Razak, V. (2011). Island Awash - Sustainability indicators and social complexity in the Caribbean. Quality-of-life community indicators for Parks. Recreation and tourism management, 43 pp. 141-161). Netherlands: Springer.

Butler, R. W. (1980). Concept of a tourist area life cycle evolution. Canadian Geographer, 24, 5-12.

Chen, Z., \& Bao, J. (2012). The spatial morphological evolution of RBD and its determining mechanism in a typical scenic tourist city: the case study of Yangshuo county. Geographical Research, 31, 1339-1351.

Chen, H., Lu, L., Zhang, J., \& Zheng, S. (2008). Analysis of spatial tourist structure and optimizing for the Zhujiang River Delta urban cluster. Scientia Geographica Sinica, 28, 113-118.

Dredge, D., \& Jamal, T. (2015). Progress in tourism planning and policy: a post-structural perspective on knowledge production. Tourism Management, 51, 285-297.

Estol, J., \& Font, X. (2016). European tourism policy: its evolution and structure. Tourism Management, 52, 230-241.

Jiang, Y., Kuang, M., Qi, D., Li, L., \& Huang, G. (2004). GIS-based evaluation, analysis and planning of tourism resources in Chongqing. Journal of Natural Resources, 19, 38-46.

Katircioglu, \& Salih, T. (2014). International tourism, energy consumption, and environmental pollution: the case of Turkey. Renewable and Sustainable Energy Reviews, 36, 180-187.

Ke, L., \& Wang, Q. (2012). Evaluation model of sustainable development in island and its application-A case study of Changhai County. Marine Environmental Science, 31, 529-533.

Keynes, J. M. (1936). The general theory of employment, interest, and money, 3 pp. 25-31). London: Macmillan \& Co.

Lee, T. H. (2013). Influence analysis of community resident support for sustainable tourism development. Tourism Management, 34, 37-46.

Lemelin, R. H., Koster, R., \& Youroukos, N. (2015). Tangible and intangible indicators of successful aboriginal tourism initiatives: a case study of two successful aboriginal tourism lodges in Northern Canada. Tourism Management, 47, 318-328.

Li, Y. (2000). Evaluation of tourist resources in coastal areas of Liaoning province. Journal of Natural Resources, 15, 46-50.

Li, Y., Li, P., \& Huang, D. (2013). Construction of an evaluation system for island tourism resources. Resources Science, 35, 304-311.

Liu, J. (2003). A research on development rules of tourism resort. Progress in
Geography, 22, 211-218

Liu, S., \& Wu, C. (2000). A GIS based model of urban land use growth in Beijing. Acta geograpaica sinica, 55(4), 407-416.

Loumou, A., Giourga, C., Dimitrakopoulos, P., \& Koukoulas, S. (2000). Profile: tourism contribution to agro-ecosystems conservation: the case of Lesbos Island, Greece. Environmental Management, 26, 363-370.

Ma, L. (2011). The characteristics of island-type tourism destination and its development mode choices - a case study of Zhoushan archipelago. Economic Geography, 31(10), 1740-1744.

Ren, S., \& Wang, S. (2011). The strategic research on the development of the ecological tourism resources in ZhouShan islands. Economic Geography, 31(2) $322-326$.

Ruhanen, L., Whitford, M., \& Mclennan, C. (2015). Indigenous tourism in Australia: time for a reality check. Tourism Management, 48, 73-83.

Sanagustín Fons, M. V., Fierro, J. A. M, \& Patiño, M. G. Y. (2011). Rural tourism: a sustainable alternative. Applied Energy, 88, 551-557.

Shen, T., \& Tian, L. (2010). A study on spatial structure and its evolution of tourism attractions in Hainan island. Tropical Geography, 30(1), 96-100.

Wang, H., Li, Y., Yang, J., \& Xing, J. (2010). A study on development potential of island tourism resources based on cognitive psychology: a case study of Guanglu island in Dalian city. Resources Science, 32(5), 886-891.

Wang, F., \& Zhu, D. (2012). Sustainable development and management of coastal tourism resources under the background of global change. Journal of Natural Resources, 27, 1-16.

Wells, V. K., Manika, D, Gregory-Smith, D., Taheri, B., \& McCowlen, C. (2015). Heritage tourism, CSR and the role of employee environmental behaviour. Tourism Management, 48, 399-413.

Wu, Y. (1998). Environmental problems in the western part of Yintan national tourism and holiday resort of Beihai city. Journal of Natural Resources, 13(3), 256-260.

Wu, C., \& Guo, B. (1991). The tourism development of scenic spot land research. Geography and Territorial Research, 7(4), 48-53.

Xi, J., Zhao, M., Wang, K., \& Chen, P. (2013). Land use evolution of growth tourismtown from 1986 to 2010: a case study of Sanpo town in Yesanpo tourism attraction in Hebei province. Geographical Research, 32(1), 11-19.

Yang, J., Ryan, C., \& Zhang, L. (2013). Social conflict in communities impacted by tourism. Tourism Management, 35, 82-93.

Yu, J., \& Wang, L. (2007). Landscape structure analyses for urban tourism planning: a case study of Dalian. Journal of Natural Resources, 22(02), 281-289.

Zhang, L., \& Gao, J. (2007). Exploring the effects of international tourism on China's economic growth, energy consumption and environmental pollution: evidence from a regional panel analysis. Renewable and Sustainable Energy Reviews, 53, 225-234.

Zhang, G., Liu, J., \& Wan, R. (2008). Functional zoning of island tourism in Qingdao. Resources Science, 30(8), 1155-1161.

Zhang, Y., \& Wang, D. (2007). Discussion on the changes of land-use and the land and sea area comprehensive utilization on Dachangshan Island. Progress in Geography, 26(3), 80-87.

Zhao, Y. (2010). Analysis of the evolution of tourism land in Zhuhai. Scientia Geographica Sinica, 30(2), 306-312.

Zhu, M., Fan, S., \& Song, T. (2012). Prospect and business of Leapfrog development of Hainan rural tourism against the background of international tourism island. Business, economics, financial Sciences, and management (pp. 309-316). Berlin and Heidelberg: Springer.

Zhu, H., Li, X., He, S., \& Zhang, M. (2001). Spatio-temporal change of land use in Bohai Rim. Acta geograpaica sinica, 56(03), 253-260.

Zhu, F., Lu, L., Yu, R., \& Bao, J. (2012). Tourism spatial structure evolution of metropolitan area: a case study of Changjiang river delta metropolitan area. Scientia Geographica Sinica, 32(5), 570-576.

Zu-yong, W., Ju-qin, S., \& Fu-hua, S. (2013). Study on the model building for the influence of the water environment on urban tourism ecological capacity. Journal of Applied Sciences, 13, 1760-1766.

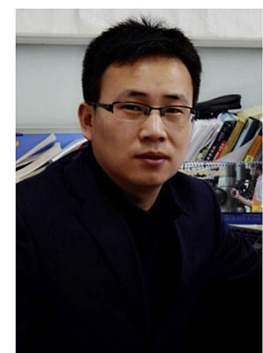

Jun Yang, PhD is an Associate Professor in the effect of human settlement and GIS at Liaoning Normal University. He has published in a wide range of journals including Abstract and Applied Analysis, Fuzzy Sets and Systems, Sustainability and the like. 


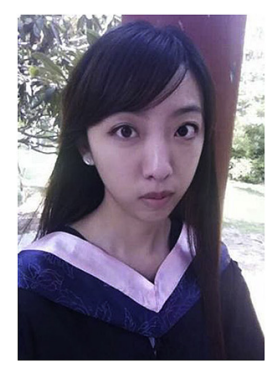

Yuting Ge, has been interested in tourism and sustainability while pursuing her master's degree in China at Liaoning Normal University. Her background is Tourism management.

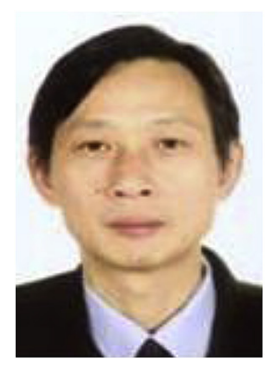

Quansheng Ge, PhD is Research Fellow, whose main research area is global changing and the director of Institute of Geographic Sciences and Natural Resources Research. He has published more than 150 papers, over 10 works and at least 30 papers $\mathrm{SCI}$. 